\title{
The advantages and backdraws of the flat-rate personal income tax
}

\author{
Attilane Ambrus \\ University of West Hungary \\ Faculty of Economics \\ Erzsebet st. 9 \\ Sopron 9400 Hungary \\ ambrusne@ktk.nyme.hu
}

\begin{abstract}
It is not an easy task for governments fighting with economic and socio-political issues to establish a suitable tax system. International and national economists argue for and against the introduction of the flat- rate personal income tax. As the practical implementation of the flat-rate tax system and the experience related to it are not uniform, it is rather difficult to generalise.

My aim is to analyse what underpins most often heard pros and cons by describing the practice in some of the neighbouring countries. After that I give an overview of the relationships that further the application of the flat-rate personal income tax in Hungary. I also take some factors into consideration on the basis of which certain amendments to laws are difficult to justify. I will describe the process of how the national linear (flat-rate) personal income tax system was established, as well as, how tax revenues may be affected by amendments to laws.
\end{abstract}

Keywords: flat-rate, personal income tax, tax burden, tax revenues, simplification. JEL Classification: $\mathrm{H} 24$.

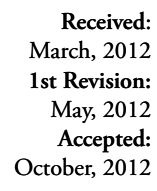

Received:

March, 2012

May, 2012

October, 2012

\section{INTRODUCTION}

When comparing the individual tax systems and considering their advantages and drawbacks, the following factors should be taken into account:

- Effect on work and performance.

Tax-payers do not react to the increase in tax burdens in the same way: some of them are incentivised to work more, others would rather prefer free-time; some others do not really deal with their actual income when building up their careers; instead typically enough they opt for tax evasion.

- Effect on savings and consumption.

People with lower incomes spend the majority of their incomes on consumption, although with increased progressivity the savings of those with higher incomes also decrease. It may result in a decline of investments. Willingness to save may rise if the tax rates are lower (Erdős, 2006). 
- Effect on the size of tax incomes.

To ensure budgetary revenues the state cannot miss a major part of tax incomes. When more incomes are needed, a simple solution is to increase the tax rates. Practice shows various solutions, often contradicting all the previous theories (see subchapters).

- Effect on simplifying the tax system.

The main argument of those supporting the linear (flat-rate) tax is to emphasise the simplification of the system. Undoubtedly, the transparency of the tax system means competitiveness, especially in case of a moderate tax rate. Administrative burdens may decrease; tax collection may become more efficient. More tax-payers can be controlled, which - in addition to predictability - may lead to a decrease in the black economy. A growing number of tax-payers and/or a higher tax base may have a positive effect on tax incomes.

\section{THE THEORETICAL APPROACH OF THE FLAT-RATE PERSONAL INCOME TAX}

Until the $19^{\text {th }}$ century the flat-rate method was widely used, after that progressive tax systems according to brackets gained popularity. In Hungary they were launched as a part of the 1909 tax reform attached to the name of Sándor Wekerle, but they entered into force only in 1922 (Burján et al, 2007). At present developed regions use a progressive tax system. It is also the same in Europe, although the picture is more diversified, because the member states of the EU insisted on the independence of their personal income tax system in the course of the tax harmonisation processes.

Due to the complexity of the systems, at the beginning of the 1980s Robert Hall and Alvin Rabushka (1995) supported the simplification of the system. They suggested that $19 \%$ rate should be imposed on all incomes; while families with incomes under 25,000 USD should be exempt from taxes. In their view the implementation of the principle of fairness is the task of the social policy not that of the tax policy. With the help of the flat-rate system considerable administrative costs can be saved (Rabushka, 2006), there is no need for tax returns, moreover, a more transparent system may also be controlled more efficiently. A classic version of a flat-rate system taxes incomes in the same way, independently of their sources: the personal income tax rate and the corporate income tax rate are the same. In practice the "flat-tax" is regarded as a type of income tax. However, according to the authors, it is closer to taxes levied on consumption, as it does not tax the accumulation of capital, or even by involving early child-care allowance that of human capital (Bauerné, 2010).

In addition to the above-mentioned facts, professional literature mentions several advantages of the flat-rate income tax, although the experiences in countries where it was launched are not homogeneous. For giving an overview of the possible advantages I regard the use of modal verbs expressing possibility to be necessary.

By the application of the flat-rate income tax:

- The tax system may become more simple (when not complicated by tax base corrections and tax allowances),

- It may encourage performance (if the tax rate is not too high),

- It may decrease tax avoidance (if the tax rate is low enough so that the tax-payer will not risk especially in case of an efficient control),

- Employment may rise (compound effect, it is influenced not only by the tax system),

- The tax incomes may rise (if one of the previous facts is implemented), 
- Bureaucracy may be reduced (controlling and recording of a more transparent system requires a smaller apparatus),

- It may enhance economic growth (compound effect),

- It may enhance savings and investments,

- The country may become competitive (it is also a compound effect, but in the case of a well-structured and transparent system this comparison is more simple, and may be more attractive with a relatively low tax burden.

The flat-rate personal income tax (in addition to the application of a tax exempt bracket) is vertically unfair; therefore its opponents regard this as one of its drawbacks. This factor can especially become important, when - compared to the previous tax burden - the flat rate results in a surplus burden in the lower wage categories, while it leads to a tax cut in higher ones.

Changes in net incomes may lead to an increase in social tensions. This effect may be reduced with the help of correction items, although it may cause the system to become more complex. According to the supporters of the progressive personal income tax, in the era of modern information technology, it is not the brackets and the rates that should be emphasised, but ensuring the transparency of the tax law.

The effect on the tax incomes is very difficult to model. With a relative low tax rate tax revenues must decline in the short-run, a rise can be predicted only with some careful estimate in the long-run. The successful operation of a tax system highly depends on the tax payment willingness of tax-payers. This fact shows differences according to countries, at the same time a predictable tax system may influence the tax payment willingness in a positive direction by efficient control and/ or strict sanctions.

The applicable tax rate should be revised from the aspect of competitiveness among the advantages, because the yields of "the tax reduction rivalry" among the countries with a more comparable tax system for investors offer three opportunities for the budget.

With reference to the flat-rate system the notion of the tax cuts always emerges. In spite of the fact that the empirical verification of the relationships is unknown, the thesis by Arthur Laffer is often referred to according to which in case of a growing tax rate the tax revenues do not rise, but fall. However, in the course of econometric analyses Mária Lackó (2009) states that a reduction in the size of tax will not result in a rise in the tax revenues together with the tax variable combined with corruption according to the pattern of the Laffer-curve.

Based on the above-mentioned facts I think that the expected effects of the transition to the flat-rate system are very difficult to predict, even in a stable fiscal environment.

\section{THE FLAT-RATE PERSONAL INCOME TAX IN EUROPE}

The European Union proposes its member states a cut in (direct) taxes imposing a burden on wages and salaries and companies' profits, as well as, a rise in (indirect) taxes levied on consumption and green taxes. In addition to this, it is also an obvious aim to ensure the adequate amount of tax revenues - if possible by widening the tax base. The World Bank calls for an application of a stable and predictable tax system in addition to decreasing the administrative tasks (and costs) (Kiss et al, 2008).

Taking the compliance obligations into account, the amendments to income tax laws in the European countries can be traced back to three factors that are often related to each other: achieving/ preserving a more favourable position in the tax competition due to globalisation, reducing the taxes imposed on work, requiring the simplification of the tax system. These driving principles appeared in the flat-rate tax reforms of the East European countries (outside the EU) (Tonin, 2006). 
It was first the Baltic countries that opened into the direction of the flat-rate system. In the pioneer Estonia the new 26\% personal income tax rate approached the average of the previous progressive system, and also the corporate income tax rate decreased to the same amount by $9 \%$. In Lithuania and Latvia the new rate of the personal income tax was implemented at the highest rate applied previously, which meant a higher tax burden than that of companies. The common feature about the tax reform of the three countries is that they chose a relatively high tax rate for transforming the personal income tax system. In Lithuania the limit of the tax-free incomes was tripled, it was also slightly raised in Latvia, while in Estonia the amount of tax has been reduced in recent years, in Lithuania it is only $15 \%$. Besides the numerous advantages of simplifying the tax system, its positive effect on the tax revenues is disputable. In Latvia there was a significant fall after a rise in the beginning, and the crisis led to an extremely sharp decrease. In November 2009 the IMF proposed Latvia to abolish the flat-rate system (Figyelö, 2009).

Table 1

The introduction of the flat-rate personal income tax in Europe

\begin{tabular}{|l|c|c|c|c|}
\hline \multicolumn{1}{|c|}{ Country } & Flat-rate adopted & PIT rates before & PIT rate after & PIT rate in 2011 \\
\hline Estonia & 1994 & $16-33$ & 26 & 21 \\
\hline Lithuania & 1994 & $18-33$ & 33 & 15 \\
\hline Latvia & 1995 & $10-20$ & 25 & 25 \\
\hline Russia & 2001 & $12-30$ & 13 & 13 \\
\hline Serbia & 2003 & $10-20$ & 14 & 15 \\
\hline Slovakia & 2004 & $10-38$ & 19 & 19 \\
\hline Ukraine & 2004 & $10-40$ & 13 & 12 \\
\hline Georgia & 2005 & $12-20$ & 16 & 16 \\
\hline Romania & 2005 & $18-40$ & 12 & 10 \\
\hline Macedonia & 2007 & $15-24$ & 15 & 12 \\
\hline Montenegro & 2007 & $16-24$ & 10 & 10 \\
\hline Bulgaria & 2008 & $10-24$ & 15 & 15 \\
\hline Czech Republic & 2008 & $12-32$ & 16 & 16 \\
\hline Hungary & 2011 & $17-32$ & & \\
\hline
\end{tabular}

Source: based on Gubucz (2010) in Balogh et al (2010) and KPGM (2011).

\section{AFTER THE BALTIC STATES RUSSIA ALSO SWITCHED TO THE FLAT-RATE PERSONAL INCOME TAX}

In contrast with the practice of the three countries, the size of the personal income tax was determined at a very low level. Before a sharp decrease in the tax rate $-13 \%$ flat rate - the average effective tax rate amounted to $14 \%$ in addition to the $12-30 \%$ progressive personal income tax rate. In spite of the flat rate progressivity partly remained, because the law ensured tax exemption up to 4800 roubles (Balogh et al, 2010). As a part of a comprehensive tax reform first of all the widening of the tax base led to a surplus income. An increase in the efficiency of the tax collection and that of control also enhanced the people's willingness to pay taxes. A curiosity of the Russian tax reform is that the difference between the personal income tax rate and the corporate income tax rate did not decrease but increase, the $37 \%$ tax imposed on corporations was regarded as extremely high. The tendency to reduce taxes was also predominant; since 2009 the corporate income tax rate has been $20 \%$. 
At the beginning of the $21^{\text {st }}$ century the number of countries opting for the flat-rate personal income tax increased: Serbia, the Ukraine, Slovakia, Georgia and Romania also voted for it.

The 19\% flat-rate tax that is uniformly applied to all tax types was introduced in the neighbouring Slovakia in 2004. Due to the foreign direct investments the economy showed a recovery, unemployment fell and compared with the previous year the tax incomes increased. In spite of these facts the relationship between cause and effect is not so clear. Investments in the car industry had already started in 2001, therefore the tax reform cannot have initiated the revival of the expansion, although it must have contributed to it later (Pogátsa, 2009). By launching a flat rate the tax allowances were dramatically cut, and as a result of this the tax burden on a considerable number of tax-payers has increased, in spite of the relatively high tax exempt bracket. In addition to determining a single rate, the government also started transforming the redistribution in order to ensure fiscal stability. At the same time, the tax reform was a part of a complex reform package. Within 10 years the GDP-related tax centralisation in Slovakia dropped by $8 \%$ to $29 \%$, it was lower only in Romania and Latvia, while in Hungary the amount of redistribution exceeded this level by $10 \%$ in 2009 (Eurostat, 2010). Slovakia was able to launch the euro only by applying a consequent economic policy; therefore it also sharply reduced the expenditure side.

The Slovak example was also regarded as a key to success by many people in the neighbouring countries, first of all predicting an increase in tax income due to job creations resulting from tax cuts, although the PReffect of the tax cuts was much stronger than its real economic consequences (Pogátsa, 2010).

The countries joining the trend include Montenegro, Macedonia, Albania, Bulgaria, the Czech Republic and since 2011 at last Hungary.

In the background of the decision the above-mentioned countries set similar objectives: decreasing tax avoidance, reducing administrative costs, enhancing employment, and as a possible positive result of all this increasing the tax revenues. The introduction of the flat-rate tax in the above-mentioned countries was not implemented in the same way, although the measures related to the transformation can be grouped according to the following factors:

- Imposing a flat rate on the major tax items (PIT, CIT, VAT) (Slovakia).

- The same size of the personal income tax and the corporate income tax (Latvia, Estonia, Romania, Macedonia).

- The personal income tax has become flat, but due to the allowances and/or a tax exempt bracket the tax burden of the incomes is not the same (in each country except Georgia).

- There is a flat-rate personal income tax without allowances (Georgia).

The above facts show that in the majority of the countries introducing a flat tax rate there was a linear tax burden. In general, it was important to maintain the tax exemption of the lowest incomes, and occasionally reinforce other - first of all - social elements through the tax system. For example in Romania tax allowance can be claimed on the basis of the tax-payer's health state and the number of dependents provided for by the tax-payer (Herich et al, 2010).

Several people tried to verify the effect of the flat rate tax system on the tax revenues, a comparison was made only for 2 years (Keen et al, 2006). Sometimes the studies describing the individual countries have come to controversial conclusions (Halmosi, 2008), therefore the significance of the positive effect cannot be justified.

Summing up the experiences of the countries introducing the flat-rate tax system, it may be stated that the greatest advantage of its launch is not expressively the flat rate, but through it the system can be made more simple and transparent. By lowering the allowances administration has been simplified and by the abolition of (at least a part of) the loopholes the tax base could be widened. Mainly those reforms are successful, in case of which the labour costs decrease, incomes from work and capital are taxed in the same way, and the tax reform is implemented as a part of a comprehensive economic political restructuring. A (more) predictable tax political environment was more attractive for the investors. 
The crisis revealed serious problems in countries with a flat-rate tax. Among the actual measures returning to the progressive taxation also emerged (Slovakia, Romania). The IMF proposed it to Latvia because of a decrease in tax incomes, while it was not introduced in Poland in spite of the proposals.

Since 2010 there have also been investigations in Finland relating to the introduction of the flat-rate tax as a result of the growing number of Estonian employees, and foreign capital investments in Estonia (Vörös et al, 2010). At present the classic Scandinavian welfare model is effective in Finland - high taxes, serious social benefits - in this way applying the tax political solutions of the East-European transition states would be surprising for many people.

\section{THE ENVIRONMENT OF TAXATION BEFORE THE LAUNCH OF THE FLAT-RATE PERSONAL INCOME TAX IN HUNGARY}

The proportion of the personal income tax among the budgetary revenues was increasing until 2008, after that it started to fall.

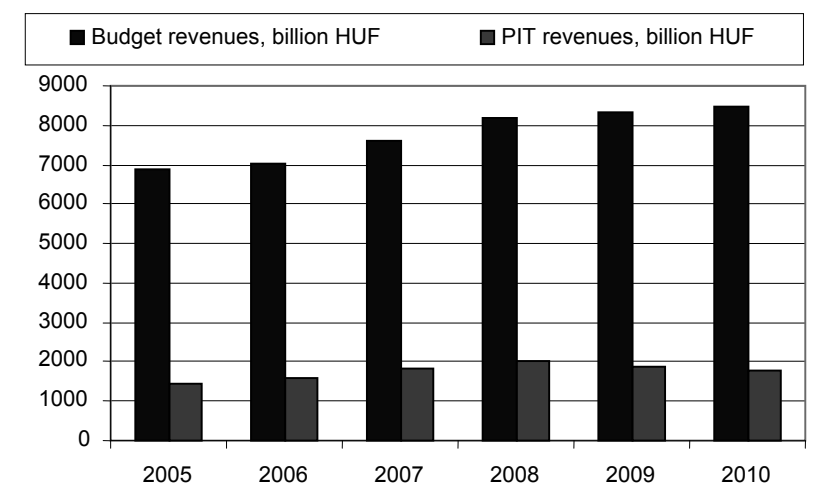

Picture 1: Personal income tax revenues in budget revenues between 2005 and 2010

Source: Own design based on data from the Hungarian Statistical Office ${ }^{1}$.

In 2009 the amount of the declared incomes stagnated as a result of the crisis. The changes in tax burden may be traced back to the changes in the legal environment. The general tax burden on incomes belonging to the aggregate tax base was affected and changed by the system of allowances.

Table 2

The formation of the declared incomes and the average tax burden

\begin{tabular}{|l|c|c|c|c|c|c|}
\hline \multicolumn{1}{|c|}{} & 2005 & 2006 & 2007 & 2008 & 2009 & 2010 \\
\hline 1 & 2 & 3 & 4 & 5 & 6 & 7 \\
\hline Incomes in consolidated tax base, billion HUF & 6391 & 7001 & 8048 & 8670 & 8301 & 8471 \\
\hline Tax of consolidated incomes, billion HUF & 1207 & 1332 & 1503 & 1636 & 1503 & 1384 \\
\hline
\end{tabular}

1 http://portal.ksh.hu/pls/ksh/docs/hun/xstadat/xstadat_eves/i_qse006c.html?144 (updated: 09.01.2012) 


\begin{tabular}{|l|c|c|c|c|c|c|}
\hline \multicolumn{1}{|c|}{1} & 2 & 3 & 4 & 5 & 6 & 7 \\
\hline Tax burden \% & $18,9 \%$ & $19,0 \%$ & $18,7 \%$ & $18,9 \%$ & $18,1 \%$ & $16,4 \%$ \\
\hline Incomes taxing separately, billion HUF & 644 & 753 & 945 & 580 & 574 & 402 \\
\hline Tax of incomes taxing separately, billion HUF & 126 & 155 & 186 & 154 & 139 & 101 \\
\hline Tax burden \% & $19,6 \%$ & $20,6 \%$ & $19,6 \%$ & $26,5 \%$ & $24,3 \%$ & $25,2 \%$ \\
\hline
\end{tabular}

Source: based on data from the Hungarian Tax Authorities².

Although in Hungary the flat-rate personal income tax was launched only in 2011, the personal income tax system had already been approaching the flat-rate system. Considering the amendments to laws in recent years, regarding there was actually one rate attached to the lower bracket that played a role with regard to both tax-payers and the declared incomes.

In 2009 a higher tax rate meant a burden for $29 \%$ of the tax-payers. However, in 2010 as a result of the fact that the bracket was extended to 5 million $\mathrm{Ft}, 90 \%$ of the tax-payers paid a lower $17 \%$ rate. Less than $40 \%$ of the declared incomes belonged to the lower tax bracket in 2009, a year later more than two-thirds of the incomes fell into this bracket.

The effect of introducing the linear (flat-rate) tax in Hungary has been modelled in several research works. According to a study by Benedek - Lelkes (2006) applying a flat-rate personal income tax system might cause a significant change in the redistribution system.

\section{THE PROCESS OF LAUNCHING THE LINEAR (FLAT-RATE) PERSONAL INCOME TAX}

Since the change of government in 2011 when computing the personal income tax a $16 \%$ flat-rate has had to be imposed. Due to the tax credits the tax burden has become neither linear nor $16 \%$ as a result of "super-grossing" tax base correction $(1,27)$ from the previous year. Therefore, the maximum amount of tax liability amounts to $20.32 \%$ in case of annual incomes (over 3,962,400 HUF) ineligible for tax credits.

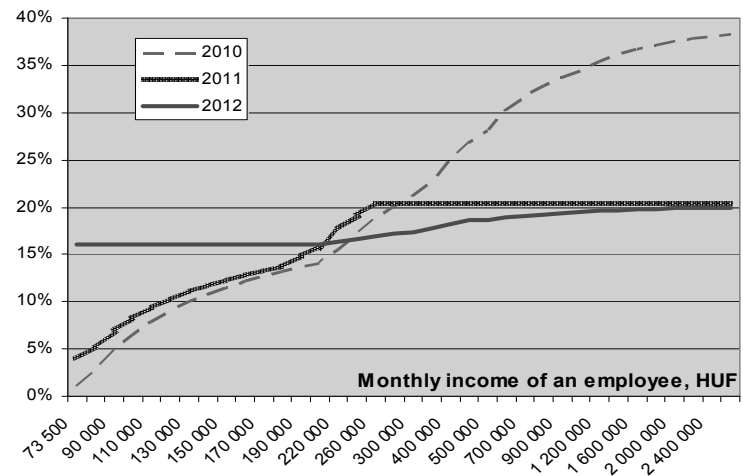

Picture 2: The formation of the proportion of tax burdens (2010-2012)

Source: Own design based on the amendments to Act CXVII/ 1995.

2 http://www.apeh.hu/magyar_oldalak/adostatisztika/szja_111017.html (downloaded: 22.10.2011) 
By phasing out the tax credit since $1^{\text {st }}$ January 2012 progressivity has decreased, in compliance with the effective regulations the tax base should be further supplemented in case of incomes belonging to the aggregated tax base and exceeding 2,424,000Ft annually.

By abolishing the tax credit and phasing out the super-grossing tax base in 2013, the linear personal income tax may be implemented. Due to allowances to families there may be large differences in tax burdens as a result of the number of dependents (Picture 3), in this way the net income of people with children is considerably higher than that of their colleagues without children.

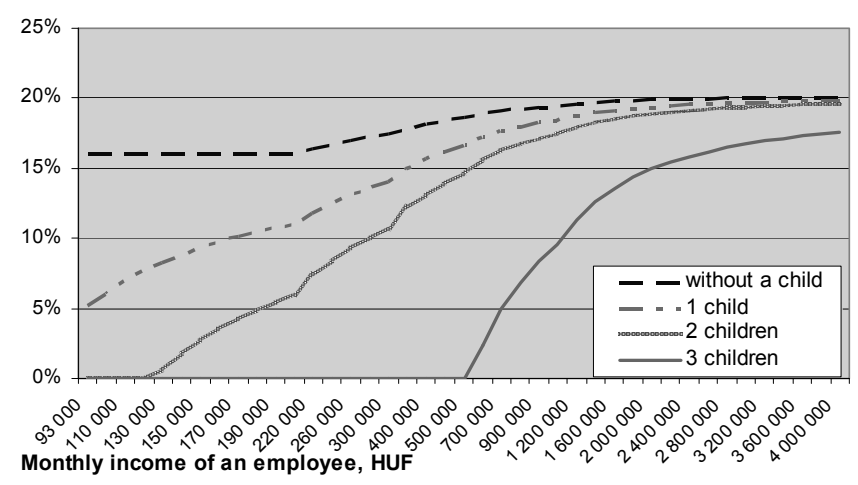

Picture 3: The tax burden with regard to the number of dependents (2012) Source: Own design based on the amendments to Act CXVII/1995.

Allowances after children may seem to be a tax for childless people, although we must not forget about self-provision through generations besides the problems of the pension system. (Ambrusné, 2010). Studying the constitutional principles of public burden, Klicsu László (2008) came to the conclusion that the principle of taxation according to performance may be implemented by allowances after children.

Among the measures towards simplification the flat rate is an important parameter. Its greatest role is to tax incomes from different sources in almost the same way, because since 2011 the majority of incomes taxed separately have been taxed at $16 \%$, therefore regulations for computing the advance tax payment and those for filing tax returns may become simpler.

\section{THE EFFECT OF LAW AMENDMENTS ON TAX INCOMES}

Decreasing the proportion of the personal income tax burden among the budgetary revenues must continue due to amendments to tax laws. Figure 4 presents that in 2010 more than two-thirds of the tax revenues derived from the payments of people with more than 3 million Ft income. As a result of the amendment to the laws, the tax burden of these incomes has been much lower since 2011. Thus, the amendment favours a smaller group of tax-payers, while it misses a considerable tax income. 


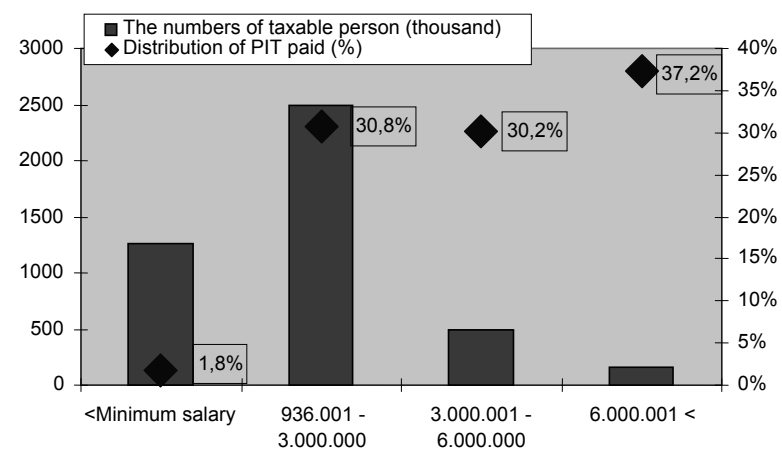

Picture 4: The number of those who declare their incomes and the distribution of taxes paid by them according to income categories (2010)

Source: Own design based on data3 by the National Tax and Customs Administration of Hungary (NAV).

On the basis of the above-mentioned facts it is not surprising that in 2011 the amount of the collected personal income tax decreased by 404 billion $\mathrm{Ft}$, as a part of which the launch of allowances for families led to a 156 billion Ft reduction. Based on the effective law for the year 2012 the budgetary revenues are expected to include a $13.8 \%$ revenue from personal income tax (Table 3 ).

This is mainly due to the abolition of the tax credit, when wages and salaries grow by $4 \%$ on average. Maintaining the level of the net wages and salaries would be ensured by a significant rise in the minimum wage and the guaranteed wage minimum, as well as, the application of a new - extremely complicated - compensation system ${ }^{4}$. In spite of the fact that the employers' cost increase would partly be offset contribution allowances, some companies are unable to increase wages and salaries according to the government decree on expected wage rise.

Table 3

Changes in revenues from personal income tax and tax burden

\begin{tabular}{|c|c|c|c|}
\hline & 2010. actual & 2011. objective & 2012. objective \\
\hline Revenues from PIT, billion Ft & 1767,9 & 1363,0 & 1550,7 \\
\hline General tax burden of aggregate incomes $\%$ & 16,4 & 13,3 & 15,1 \\
\hline The proportion of PIT among budgetary revenues \% & 21,0 & 16,5 & 13,8 \\
\hline The proportion of PIT related to the GDP \% & 6,6 & 4,8 & 5,3 \\
\hline
\end{tabular}

Source: Own design based on data from $\mathrm{HSO}^{5}$ and the Budgetary Plan ${ }^{6}$.

A lower level of revenues from personal income tax would be -first of all - replaced by the budgetary objective by increasing taxes on consumption. Besides the predicted rise in turnover a $27 \%$ tax rate was launched in 2012, which is the highest in Europe at present. In order to change the structure of tax cuts, as

3 http://apeh.hu/data/cms199863/sajtotajekoztato_20110913_tao_szja_eva.pdf (downloaded: 13.09. 2011.)

4 http://nav.gov.hu/data/cms211509/utmutato_elvart_beremeleshez_0102.pdf (downloaded: 12.01.2012)

5 http://portal.ksh.hu/pls/ksh/docs/hun/xstadat/xstadat_eves/i_qse006c.html?144 (updated: 09.01.2012.)

6 http://www.parlament.hu/irom39/04365/adatok/fejezetek/42.pdf (downloaded: 09.01.2012.) 
well as, replace the missing revenues from personal income tax, excise duties were sharply raised in several steps and some new taxes (e.g. national health tax on consumption) were launched.

\section{CONCLUSION}

The supporters of the flat-rate tax emphasise the proportional tax burden and the simple system. Regarding the personal income tax a single rate is rarely applied. In countries that choose this method, the amount of tax is so low that there is no need for other allowances. The different correction items may decrease the transparency of the system. In some countries tax credits do not depend on income limit, therefore in spite of the flat rate the tax system is progressive. In a more complicated version people with higher incomes are excluded from the benefits. Because of the abolition of tax credits, the marginal tax rate will be higher, and above the income limit the tax will be linear. Romania also applies a model similar to that of Hungary. As a result of the correction items the average tax rate is not constant. Simplification may take place by the radical abolition of the allowances, even when applying a progressive tax system.

The proportional public burden may be supplemented by restructuring the tasks of the social welfare system with the aspect of fairness. Tax avoidance can be decreased by a reasonably chosen tax rate, as well as, by efficient control. The amount of this is very difficult to estimate. Even a consequent tax policy can influence a change in the tax morale with difficulty. However, many people agree that both employers and employees are interested in avoiding taxes due to the currently high tax wedge, therefore in addition to a cut in the personal income tax burdens only a reduction in the contribution burdens may lead to some considerable result.

The positive impact of the linear personal income tax on the recovery of the economy, as well as, a growth in the tax incomes in case of the investigated countries is not obvious. In addition to a growing GDP growth, the linear personal income tax is likely to become a tool for a successful economic policy. For ensuring competitiveness the restructuring of the tax system is a key but only one of the elements of the structural reforms.

When launching the flat-rate tax certain countries show similar features, yet there are some differences in the economic indicators. Comparison is extremely difficult, because the taxpayers come from a different economic and cultural environment, thus the consequences of the same (or similar) measures may differ.

With regard to the launching environment in Hungary, there should be a focus on the instable economic environment which especially makes the expectations related to the flat-rate tax system uncertain. During economic recession the budget may bear a significant reduction in the tax burdens only by sharply cutting expenditures. A predictable tax system that is in compliance with the social security system is an important pillar of the social security system.

It is a very complex issue to state whether the effects of the introduction of the flat-rate tax system result in positive changes. Predictions and even analyses following the launch are made difficult by the fact that the measure also involves tax cuts and is determined both in time and space and takes place in the actual external and internal economic environment.

\section{REFERENCES}

Ambrus, A.R. (2010), Egyszerűsítést! Egy a kulcs? „Hitel, Világ, Stádium”Nemzetközi Tudományos Konferencia, NYME Sopron, 2010. november 3. (CD-n megjelent)

Balogh, L., Gál, V., Parádi-Dolgos, A. (2010), Fából vaskarika? Egykulcsos családi jövedelemadózás lehetösége Magyarországon nemzetközi tapasztalatok alapján, „Hitel, Világ, Stádium” Nemzetközi Tudományos Konferencia, Sopron, 2010. november 3. (CD-n megjelent). 
Bauerné Fülöp, K. (2010), Az egykulcsos adó születése, Számvitel - Adó - Könyvvizsgálat 2010/11. p.506.

Benedek, D., Lelkes, O. (2006), A magyarországi jövedelem-újraelosztás és egy egykulcsos adóreform vizsgálata mikro-szimulációs modellel, Közgazdasági Szemle, LIII. évfolyam, 2006. július- augusztus, pp. 604-623.

Burján, Á., Szebellédi I., Sztanó Imréné-Tóth, J. (2007), Adók és támogatások alapjai, SALDO. pp.31-70.

Erdős, T. (2006): Növekedési potenciál és gazdaságpolitika. Akadémiai Kiadó, Budapest. pp.44-52.

Eurostat (2010) (letöltve: 2011.01.07) http://epp.eurostat.ec.europa.eu/portal/page/portal/government_finance_statistics/data/main_tables

Figyelő (2009): Az egykulcsos adó ellen a Valutaalap (letöltve: 2011.01.07)

http://www.figyelo.hu/makro/20091104/egykulcsos_ado_ellen/

Hall, R., Rabushka A.E. (1995), The Flat Tax. Hoover Institution, Stanford.

Halmosi, P. (2008), A személyijövedelemadó-rendszer helyzete és aktuális kérdései a fejlett országokban, Pénzügyi Szemle, 3. pp. 475-485.

Herich, Gy., Láng, J., Pál-Antal, I., Radics A, Rybaltovszki, P., Sőregi Danics, Á., Szoboszlai M. (2010), Adózás Európában-Kelet-Közép-Európa, Penta Unió, Pécs, p.118.

Keen, M., Kim, Y., Varsano, R. (2006) The „Flat Tax(es)”, Principles and Evidence. IMF Working Paper 06/218.

http://www.imf.org/external/pubs/ft/wp/2006/wp06218.pdf (letöltve: 2011.01.09)

Kiss, S.Cs., Scharle Á., Szabó B., Szabó P. A. (2008), Adóreformok Európában, Külgazdaság, 2008, 52. évf. 9-10. szám, pp. 7-33.

Klicsu, L. (2008) Fenntartható társadalom - egykulcsos adó, Pénzügyi Szemle, 2008/4. pp. 707-723.

KPGM (2011), KPMG’s Individual Income Tax and Social Security Rate Survey 2011

http://www.meijburg.nl/nl/kennis/publicaties/overige-publicaties/Documents/Individual_Income_Tax_2011.pdf (letöltve: 2012.01.09)

Lackó, M. (2009), Az adóráták és a korrupció hatása az adóbevételekre, Az OECD-országok összehasonlítása, 2000-2004.

Közigazgatási Szemle. LVI. évf., 2009. június pp. 526-545.

Pogátsa, Z. (2009), Álomunió - Európai piac állam nélkül, Nyitott Könyvmühely, Budapest, pp.172-181.

Pogátsa, Z. (2010), Orbán csomagja és a magyar választások.

http://www.portfolio.hu/tool/search.tdp?q=Orb\%E1n+csomagja+\%E9s+a+v\%E1laszt\%E1sok\&x=12\&y=10 (letöltve: 2010.06.10).

Rabushka, A.E. (2006), Flat tax principles and issues, International Academic Forum on Flat Tax Rate, Centre of Excellence in Finance, Bled, Szlovénia, 2006. február 3-4. http://www.cef-see.org/index.php?location=1094 (letöltve: 2008.04.16)

Tonin, M. (2006), The Effects of the Minimum Wage in an Economy with Tax Evasion, Institute for International Economic Studies, Stockholm University, Seminar Papers, p.747.

Vörös, Gy., Kodenko, J., Komáromi, K. (2010) Az egykulcsos személyi jövedelemadóról, Pénzügyi Szemle, 2. szám, pp. 347-363. 